\title{
Europe's nuclear woes: Mitigating the challenges of the next years
}

\section{Ulrich Kühn, Shatabhisha Shetty \& Polina Sinovets}

To cite this article: Ulrich Kühn, Shatabhisha Shetty \& Polina Sinovets (2017) Europe's nuclear woes: Mitigating the challenges of the next years, Bulletin of the Atomic Scientists, 73:4, 245-254, DOI: $10.1080 / 00963402.2017 .1338022$

To link to this article: http://dx.doi.org/10.1080/00963402.2017.1338022

册Published online: 19 Jun 2017.

Submit your article to this journal $\pi$

Џll Article views: 107

Q View related articles $\circlearrowright$

View Crossmark data \lceil 


\title{
Europe's nuclear woes: Mitigating the challenges of the next years
}

\author{
Ulrich Kühn, Shatabhisha Shetty and Polina Sinovets
}

\begin{abstract}
As long as the relationship between Russia and the West continues to be confrontational, the urgent task will be to stabilize and manage the confrontation. For NATO, this primarily means balancing deterrence and assurance measures to its easternmost allies without entering a new arms race. NATO should step up its efforts to foster talks with Russia on current military threats and on arms control, possibly by seeking reconstitution of the NATO-Russia Council as a crisis management forum and mechanism for dialog, dealing with dangerous military incidents and better communicating each side's intentions. As for the Intermediate-range Nuclear Forces (INF) Treaty crisis and the interlinked issue of the European missile defense, US officials should consider face-saving options to reassure Russia that Western missile defense installations have no offensive capabilities - provided that Russia convinces the new US administration that it has returned to compliance with the INF Treaty. Over the mid- to long-term, NATO and Russia must initiate a serious and open dialogue about the two core issues at stake - the freedom and sovereignty of states to seek alliance membership and the (contradicting) Russian interest of maintaining a sphere of influence over its "near abroad." A well-prepared conference - akin to the 1975 Helsinki Summit, with various preceding rounds of consultations at ambassadorial level, and including the nonaligned states in Europe - might be a way to kick-start the discussion.
\end{abstract}

\section{KEYWORDS}

NATO; Russia; nuclear weapons; arms control; deterrence; missile defense; INF Treaty
Over the coming decade, Europe will be faced with a series of difficult challenges in the nuclear realm. The most significant, from which all the others flow, will be managing the nuclear relationship with Russia. Since the start of the Ukraine crisis, relations between NATO and Russia have further deteriorated, with NATO allies expressing concern over Russia's belligerent rhetoric on potential nuclear weapons use. In addition, serious disagreements between the United States and Russia as well as between NATO and Russia over nuclear weapons policies have increased over recent years with many predating the Ukraine crisis. These include Moscow's alleged violation of the Intermediate-range Nuclear Forces (INF) Treaty, Russian exercises involving simulated nuclear weapons use, and the ongoing Russian nuclear modernization program.

The nuclear challenges facing Europe are interconnected. If the West's relationship with Russia continues to be confrontational, the urgent task will be to manage that confrontation. For NATO, this requires striking a balance of deterrence and assurance measures for its allies, while avoiding a new arms race with Russia. Such efforts should include maintaining restraint in the nuclear realm while concentrating on conventional deterrence.
NATO should step up its efforts to foster dialogue to stabilize and manage the current confrontation. This includes dialog about the most contentious issues such as the INF Treaty and missile defense. Such talks could be undertaken in a reconstituted NATO-Russia Council (NRC). But arms control efforts alone will not mend the relationship. In parallel, the core problems underlying the conflict between Russia and the West must be addressed above all the future of NATO enlargement.

\section{The renaissance of nuclear signaling}

Since the beginning of the Ukraine crisis, Russia has engaged in a variety of dangerous practices under the rubric of "nuclear signaling." Increased patrols of nuclear-capable Russian aircraft, violations of other states' airspace, military incidents with NATO allies and partners, and loose talk about the possible use of nuclear weapons - including statements by President Vladimir Putin and other senior Russian officials highlighting nuclear "resolve" to underscore Russia's status as a global nuclear power - have all raised significant concern in capitals across Europe.

In addition, Russia has continued or stepped up a number of worrisome nuclear policies already in place before the Euromaidan protests in Ukraine: its practice 
of integrated conventional/nuclear military exercises (including simulated nuclear attacks on neighboring states such as Poland); a robust nuclear modernization program in all three legs of Russia's nuclear triad (intercontinental ballistic missiles, strategic nuclear bombers, and strategic nuclear submarines); the maintenance of up to 2,000 tactical nuclear warheads for short-range systems; and (perhaps) an ambiguous, though unconfirmed, doctrine on possible nuclear weapons use to "de-escalate" a conventional crisis. ${ }^{1}$

These policies have three significant implications for Europe. First, they underscore that Russian reliance on nuclear weapons for different policy purposes is unlikely to lessen over the coming years. Second, Russia no longer shies away from high-risk tactics that might ultimately involve its nuclear arsenal to intimidate its neighbors and unnerve NATO. Third, NATO cannot let this go unanswered if it wants to maintain alliance unity and deter Russia from continuing down this dangerous path.

In comparison, NATO's counter-messaging has been modest so far. Initially, one could argue that this was primarily because NATO was unwilling to provoke or escalate the Ukraine crisis, or that NATO is unpracticed in the art of nuclear signaling 25 years after the end of the Cold War. As the NATO-Russia crisis continued, nuclear signaling from NATO and in particular from its most powerful member, the United States, increased. Non-routine long-range flights to Europe of strategic nuclear bombers increased in frequency and were publicized for the first time. ${ }^{2}$ This is significant; NATO rarely publicly disclosed information on its nuclearrelated activities and exercises in the past. ${ }^{3}$ This growing visibility includes the deployment of US nuclear-capable heavy bombers (B-2s and B-52s) to the United Kingdom, which was previously a rare occurrence, and their participation in two NATO exercises in the Baltic States. As well as nuclear counter signaling to Russia, these measures were also intended to provide reassurance to the eastern-flank allies.

Washington in particular undertook further public efforts to demonstrate its commitment to its European partners. This included a statement by General Philip Breedlove, then-Commander of NATO's United States European Command (EUCOM), to the US House Armed Services Committee in February 2015. "The US stands side-by-side with our NATO Allies to provide safe, secure, reliable, and effective nuclear forces to deter aggression against Alliance members [...]" Breedlove said, "and as part of Operation Atlantic Resolve, EUCOM has forged a link between STRATCOM Bomber Assurance and Deterrence missions to NATO regional exercises." 4
He added an even more pointed comment: "Operation Atlantic Resolve uses US access and strategic reach to develop a unified response to revanchist Russia."

While nuclear signaling has increased on both sides, the readiness levels of NATO's dual-capable aircraft in Europe have only changed marginally since the start of the Ukraine crisis. ${ }^{6}$ According to NATO's latest public announcement, it would take weeks for NATO's nuclear forces in Europe to be readied for launch. ${ }^{7}$ Russia integrates its conventional and nuclear forces in some military exercises; NATO has shown restraint by not instituting such integration.

For some in NATO, this puts the alliance in an uncomfortable position. On the one hand, not responding to Russia's increased nuclear signaling could be misread by Moscow as a sign of weakness, potentially helping to escalate a crisis with Russia. On the other hand, reacting to Moscow's signaling in kind could as well spur escalation, by heightening the threat Russian policy-makers and military officials might already feel from the conventional military superiority that NATO and the United States hold.

\section{Readjustment of nuclear doctrines and postures}

As a reaction to Russian nuclear signaling, there have been calls for NATO to readjust its nuclear strategy in line with its recently strengthened conventional deterrence and defense posture. ${ }^{8}$ These include calls by former Polish President Lech Walesa in 2014 for Poland to lease nuclear weapons ${ }^{9}$ and by the Polish Deputy Defense Minister in December 2015 for the country to participate in NATO's nuclear-sharing arrangement. ${ }^{10}$ In December 2015, US Secretary of Defense Ash Carter suggested that NATO planners are at least considering future options for integrated planning and exercises for conventional and nuclear forces. ${ }^{11}$

Although the 2014 NATO Summit in Wales reaffirmed that NATO remained a nuclear alliance and would undertake "the most significant strengthening of our collective defense in decades," there were no alterations to its nuclear policy. ${ }^{12}$ The 2016 Warsaw Summit presented small but arguably significant changes on nuclear policy with the relevant paragraphs in the Final Communiqué showing a slight hardening of the language, as compared to the 2010 Strategic Concept and the 2012 Defense and Deterrence Posture Review that form the basis of NATO nuclear policy. ${ }^{13}$ Analysis of the 2016 communiqué reveals the reintroduction of the language of "peacetime basing of nuclear forces," which was absent from the 2012 review. The renewed emphasis on US nuclear weapons 
"forward deployed in Europe" in the 2016 documents stands in contrast to both the 2010 and 2012 documents, which indicate that the alliance would explore further reductions of non-strategic nuclear weapons in Europe as long as reciprocal measures were undertaken by Russia. ${ }^{14}$

The 2010 Strategic Concept stated that "the circumstances in which any use of nuclear weapons might have to be contemplated are extremely remote" [emphasis added]. The Warsaw Communiqué removed the reference to contemplation while placing a slightly stronger emphasis on nuclear deterrence and potential nuclear weapons use. ${ }^{15}$ This was designed to demonstrate NATO's resolve, conveying that any use of nuclear weapons, even in a "limited" fashion, would be considered unacceptable. It was also an attempt to deter any Russian use of its alleged "escalate to deescalate" strategy whereby nuclear weapons are used in a limited war to de-escalate a crisis. ${ }^{16}$

Moreover, a new sentence was introduced in the 2016 communiqué, explicitly referencing the strategic nuclear forces of the United Kingdom and France. This could be interpreted as strengthening NATO nuclear deterrence by emphasizing the role of British and French strategic forces as separate centers of decisionmaking. ${ }^{17}$ Although France does not assign its nuclear weapons to NATO or participate in NATO's Nuclear Planning Group, its ambassador participates in the North Atlantic Council (NAC) strategic discussions and would have a say in the language in final communiques issued at the end of NATO summits. France therefore has some influence over what NATO agrees internally and says publically about its nuclear policy and posture. ${ }^{18}$

The UK's nuclear forces are assigned to NATO and it participates in all of NATO's nuclear forums. The UK considers its nuclear weapons not only vital for domestic security but also as part of the alliance's deterrent posture. ${ }^{19}$ The British parliament vote in July 2016 to replace its existing submarine fleet ensures that the UK retains its nuclear capability for at least the next 50 years. Barring a dramatic change, this will also mean that these weapons are assigned to NATO for decades. $^{20}$

The 2016 Warsaw Summit language on nuclear policy and use does not significantly depart from the 2010 and 2012 documents, with no announced changes to deployments, basing arrangements of B-61 bombs, or to the interoperability of NATO's conventional and nuclear forces. Yet, NATO's nuclear capabilities are being updated as part of a modernization plan that predates Russia's actions in Ukraine. This takes the form of the US life-extension program for its B-61 tactical nuclear weapons, which are the backbone of NATO's nuclear sharing arrangements in Europe. An estimated 180 B-61 warheads are deployed in six bases in Germany, Belgium, the Netherlands, Italy, and Turkey. ${ }^{21}$ These will be replaced by updated B-61-12 precision-guided weapons that have greater accuracy and ability to penetrate the earth including hardened targets. $^{22}$ The warheads in these "modernized" bombs will also allow yields to be varied, to limit collateral damage. ${ }^{23}$ Furthermore, the fighter-bombers that these five countries now assign to carry B-61s (if ever necessary) are also in the process of being replaced. A new stealth fighter jet, the Joint Strike Fighter or F35A, is advertised as providing "greater survivability and access" as compared to the older generation of aircraft currently in use. ${ }^{24}$

Critics argue that the modernization process could lower the threshold for nuclear use. ${ }^{25}$ This line of reasoning holds that the B-61 enhancements will make these weapons more "usable." 26 NATO and Washington reject such claims, arguing that the B-61 life-extension program is simply designed to replace an aging warhead that is reaching the end of its service life. Accordingly, the B-61-12 is not a "new warhead" nor does it provide improved military capability. ${ }^{27}$

Nonetheless, the argument that the B-61 modernization, coupled with the introduction of the F35A, not only prolongs NATO's nuclear assets in Europe but also improves the alliance's targeting capabilities is compelling. Together with the more robust use of nuclear language in Warsaw and the almost complete disappearance of calls to withdraw the B-61 from countries such as Germany or Belgium, this development conveys a clear message: The words and deeds of nuclear deterrence are back in Europe.

This development clouds any prospects for negotiating reductions in non-strategic nuclear arms with Moscow, which had halted even before the Ukraine crisis. Back in 2012, NATO stated that it would look to reduce its stockpile of non-strategic nuclear weapons as long as Russia undertakes reciprocal measures. Discussions were underway at the NRC on how to devise some tentative confidence-building measures in the realm of transparency, but talks then stalled in 2013 to Russian lack of interest. Russia is estimated to have around 2,000 non-strategic nuclear weapons, ${ }^{28}$ with most of them reportedly located in the proximity of Russia's borders with EU and NATO countries, ${ }^{29}$ and maintains that these are necessary to offset NATO's conventional superiority. ${ }^{30}$ If NATO were to give greater impetus to its forward-deployed assets, Russia would be less inclined to reduce its stockpile and may even move toward modernizing this category of weapons. 
Pursuing reductions of non-strategic nuclear weapons with Russia will become even more challenging, because Moscow already argues that its non-strategic nuclear weapons are meant to compensate for its conventional inferiority, not for NATO's nuclear systems in Europe. The existing asymmetry in non-strategic weapons between NATO and Russia may increase if NATO continues to enhance conventional capabilities in Central and Eastern Europe.

\section{Missile defense in Europe}

Beyond the problematic effects of the modernization of US non-strategic nuclear weapons and Russian nuclear signaling in Europe, the issue of missile defense complicates the nuclear situation in Europe. Recognizing the relationship of nuclear offense and defense to mutual deterrence, the United States and the Soviet Union signed the 1972 Anti-Ballistic Missile (ABM) Treaty, which Moscow hailed as "the cornerstone of the strategic stability." 31 When the United States declared its withdrawal from the ABM Treaty in 2001, in Moscow's view, Washington confirmed suspicions that it was attempting to tip the strategic balance in its favor, posing a direct challenge to Russia's strategic second-strike capabilities.

To make matters worse - from a Russian perspective, at least - the United States under President George W. Bush stepped up its missile defense efforts and agreed to bilateral arrangements with its European allies for the construction of a so-called third site of US missile interceptors in Europe. This site was to be located in Poland and supported by a radar station in the Czech Republic. The Russian response to this development was unequivocally negative, and even though one could argue that the issue of ballistic missile defense was purely bilateral in nature, the political fallout also affected European security and arms control more broadly. The first visible victim of the deteriorating US-Russian relationship was the Conventional Armed Forces in Europe (CFE) Treaty which Russia "suspended" in 2007. ${ }^{32}$ After President Obama took office, the United States cancelled the Bush proposal but continued its efforts to create a European missile defense architecture to counter possible missile threats emanating from the south of Europe (meaning Iran). This European Phased Adaptive Approach (EPAA) is composed of land and sea-based Aegis missile defense elements deployed, or under construction, in Romania, Poland, and Turkey as well as on ships in the Mediterranean and the Baltic Seas.
The biggest difference between the Bush administration approach and the EPAA involved the range of missiles that could be targeted; the EPAA was not to have a capability against missiles of strategic ranges (above 5,500 kilometers). Originally, US military planners designed this missile defense system to consist of four sequential phases, one of which - Phase IV Moscow voiced concern about, because it allowed for the deployment of faster SM-3 IIB interceptors in Poland. According to Moscow, these interceptors would have the potential to intercept even Russian ICBMs. ${ }^{33}$ Also, the Russians criticized the fact that the new X-band radar could see deeply into Russian territory.

But when Washington abandoned Phase IV and decided to limit the deployments to (slower) SM-3 IIA interceptors with non-strategic capabilities, Moscow again expressed its disappointment. The main reason was the absence of an officially defined, legal missile defense framework that would guarantee Moscow the continued integrity of its strategic deterrent. Russia took issue with what it perceived to be the prospect of an open-ended US missile defense architecture in Europe and other parts of the world.

For the Obama administration, such legal guarantee was never a viable option, given the resistance by the US Congress to any "artificial" limits on US missile defenses. So, Moscow resorted to military countermeasures. Aside from citing missile defense as one of the prime drivers for modernizing its aging strategic forces, ${ }^{34}$ Moscow plans to respond to the EPAA by deploying offensive systems in the south and west of its country "to ensure Russia's capability to take out any part of the US [missile defense] system in Europe."35 This will include increased deployment of the newest Russian sea-launched cruise missile (SLCM), the Kalibr, which was successfully employed by Russia during its ongoing military operation in Syria. The Kalibr model is most likely of dual-use, meaning that it could be mounted with a conventional or a nuclear warhead, and it has a range between 1,500 and 2,500 kilometers, providing Russia with the potential to strike any target in Europe from its territory. ${ }^{36}$ For now, it is expected that Russia will deploy the Kalibr at its naval bases in Sevastopol and Novorossiysk to hold at risk the southern direction (e.g. the EPAA missile defense site in Deveselu, Romania) and at the naval base in Kaliningrad to be able to target the missile defense site in Poland. ${ }^{37}$ This mission could also be supported by the deployment of the latest generation of Russian airlaunched cruise missiles and short-range Iskander missiles in the Kaliningrad oblast. The latter missiles could reach almost all of Poland and parts of Germany. 
The missile defense situation provides Moscow with a convenient, and at some point even reasonable, argument to counter US allegations that Russia has violated INF Treaty. Russian officials often refer to the potential "breach" of the INF Treaty by the United States, ${ }^{38}$ noting that the EPAA SM-3 vertical launch systems are the same as those used to launch cruise missiles such as Tomahawks from AEGIS-capable ships. In essence, the Russian leadership seems to fear the scenario of a decapitating strike against its command and control posts, using cruise missiles launched from missile defense sites in Romania and Poland.

\section{The INF crisis}

The most serious nuclear challenge for Europe in the next years could be the lingering crisis over the INF Treaty. ${ }^{39}$ Since 2014, the US government has consistently accused Russia of violating the INF by developing "a ground-launched cruise missile [GLCM] with a range capability of 500 to 5,500 kilometers." ${ }^{40}$ On 8 March 2017, General Paul Selva, the vice chairman of the US Joint Chiefs of Staff, told the House Armed Services Committee that "we believe that the Russians have deployed a land-based cruise missile that violates the spirit and intent of the Intermediate Nuclear Forces Treaty." ${ }^{\prime 1}$ He therewith confirmed earlier reports by the New York Times that "the Russians now have two battalions of the prohibited cruise missile," one deployed at the Kapustin Yar missile test site and the other shifted "from that test site to an operational base elsewhere in the country." ${ }^{32}$ Diplomatic efforts to resolve US compliance concerns have yielded no satisfactory outcome. Instead, Russia tabled a number of counter charges related to the US-led Aegis ashore ballistic missile defense program in Europe and the use of drones. ${ }^{43}$ Parties to the treaty met at the Special Verification Commission (SVC), the treaty's consultation mechanism, in mid-November 2016.

Several US security experts have issued warnings that the INF crisis could make further arms control endeavors with Russia impossible. ${ }^{44}$ These pundits argue that "if a New START follow-on treaty could be negotiated, it would have little chance for US Senate ratification if the INF Treaty compliance issue had not been resolved." ${ }^{\prime 5}$ Without a follow-on treaty to New START, which expires in February 2021, the USRussian nuclear relationship would be reduced to a state of almost complete non-transparency and unpredictability. In that case, the only viable option for preserving strategic arms control would be the onetime extension of New START for another five years, which would not require Senate advice and consent. If the non-compliance issues and accusations relating to the INF are not resolved, Cold War and post-Cold War era arms control agreements could well unravel.

Putting arms control concerns aside, the INF crisis could also lead to the reintroduction of intermediaterange nuclear weapons to the European theatre. For this to occur, Russia would officially pull out of the INF Treaty or reliable evidence would be found determining that Russia is in material breach of the treaty, producing and deploying INF-prohibited groundlaunched cruise missiles west of the Urals (as the latest revelations might indicate). This would be a significant game changer for European security, no matter what the Russian intentions, and NATO would come under enormous military and political pressure - with increasing calls for Washington, in particular, to formulate an answer to the Russian deployments. This potential escalation cycle has already led the US Department of Defense to look into possible military options to respond to this scenario. ${ }^{46}$ Potential options could range from increasing missile defenses in Europe, over deploying US conventional-armed airand sea-launched cruise missiles (SLCMs), to extreme countermeasures such as developing and deploying nuclear-capable ground-launched Tomahawks, perhaps even launched from modified MK-41 launchers in Romania and Poland under an altered basing arrangement.

To prevent such a scenario, the West would need to know the answer to a simple question: Why would Russia test and perhaps deploy a cruise missile forbidden by the INF Treaty? Even though all answers to this question fall in the realm of speculation at this point, enumerating some possibilities might give indications as to Russian concerns.

One reason Russia might want an intermediaterange capability could involve fear of a decapitation first strike with cruise missiles launched from the two EPAA missile defense sites in Romania and Poland. Another reason might center on hedging: Russian military planners might want a GLCM with INF ranges in place, just in case the United States were to pull out of the INF. ${ }^{47}$ A third - and not inconceivable - reason might be that the INF crisis is yet another political tool to unnerve and threaten NATO. A new Russian intermediate-range cruise missile might be yet another sign of Russian intent to take on the role of an irresponsible and, may be, even unpredictable nuclear power that would be better left alone in its "sphere of influence" in order to avoid possible escalation - that is, it would be a move aimed at inducing the West to effectively accept a Yalta model of dividing lines in Europe. 
Last but not least, the Russian actions might not be related to the European equation at all and might reveal more about Moscow's concerns with regard to its southern neighborhood, including China.

\section{Negative effects of Europe's re-nuclearization}

Europe is on the brink of a new nuclear era. The postCold War period of continued downsizing of nuclear weapons arsenals, together with the policies of devaluing nuclear weapons and postures in Europe, is over. The West and Russia face another round of increased competition and confrontation coupled with deepening mistrust. No quick fix or magical silver bullet will remove the structural problems that afflict the relationship. Instead, the already visible negative effects of these trends will most likely further increase.

To begin with, nuclear disarmament in Europe is moribund, at least in the short term. Responding to Russia's aggressive nuclear posturing by strengthening NATO's nuclear policy would only accelerate the shift away from the post-Cold War trend of reducing the role and number of nuclear weapons in Europe. In broader terms, this shift could cause additional negative repercussions, damaging efforts to reduce the role and salience of nuclear weapons in other parts of the world. In addition, re-nuclearization of Europe would be politically problematic, given that NATO's Western European members face publics and parliaments that do not support a return to Cold War nuclear practices. Ignoring those national majorities would be particularly worrisome in times of populist movements that claim political elites do not care about "ordinary people."

Beyond such general effects, the unfolding military tit-for-tat between Russia and NATO will not only deepen existing mistrust but possibly lead to very real arms race dynamics. One example: mutual nuclear modernization and enhanced reliance on non-strategic weapons. These policies will increase the possibility of misunderstandings between NATO and Russia and ultimately bury the last tentative efforts to effectively reduce the role of nuclear weapons in Europe. In that regard, the inability of both US and Russian administrations to find a mutually satisfactory way to smooth over the challenges arising from missile defense policies has turned the EPAA into one of the most serious stumbling blocks impeding further nuclear reductions. The missile defense dispute between the United States and Russia also serves as an additional driver for Russian nuclear modernization programs.

The INF crisis could have severe consequences for both Europe and Asia. As a worst case scenario, it could ruin the entire remaining system of US-Russian nuclear arms control for years to come and lead to a serious debate amongst NATO members about reintroducing INF-range cruise missiles to the European theater. That's to say, the INF crisis might result in a historical throwback, creating a "nuclear Europe" akin to the early 1980s.

Classical arms control measures will most likely not be sufficient to overcome the political and normative divide separating Russia and NATO. This is primarily for three reasons: Even under best conditions, the changing global order might allow only one more round of bilateral US-Russian nuclear reductions before third parties, such as China, will have to be considered. Also, the gradual deterioration of arms control agreements since the end of the 1990s has stigmatized arms control in both Moscow and Washington, with both sides showing disappointment with the actions of each other. And finally, as Samuel Charap and Jeremy Shapiro note, cases like the INF crisis are unlikely to be resolved as long as the West and Russia do not engage "in addressing the core issue in the dispute, namely the regional order in post-Soviet Europe and Eurasia" 48 [emphasis added].

\section{Some recommendations for the next years}

In the absence of a larger and long-term effort at addressing the "core issue," and as long as the West's relationship with Russia continues to be confrontational, the urgent task will be to stabilize and manage the confrontation.

For NATO, this primarily means balancing deterrence and assurance measures to its easternmost allies without entering a new arms race prone to dangerous miscalculations. So far, the conventional measures enacted at the 2014 Wales Summit and further supplemented at Warsaw provide credible, flexible, and responsive assurance to allies in Central and Eastern Europe. They could be augmented by some modest additional measures such as the rotational deployment of lightly armed multinational border patrol units for the three Baltic States.

In that vein, NATO allies should recognize that the continuous rotational deployment of multinational forces and equipment is a far more credible deterrent than nuclear weapons. This is demonstrated by the fact that the current deployments of non-strategic nuclear weapons in Europe alone were not able to provide sufficient reassurance of NATO's deterrence capabilities or Article V resolve to members in the East. Allies should therefore continue showing restraint with respect to NATO's nuclear policy and posture, resisting 
calls to abandon NATO's earlier pledge not to deploy or store nuclear weapons on the territories of its newer members ${ }^{49}$ or to raise the readiness levels of its nuclear forces in Europe. Instead, NATO and other countries must continue to publically denounce Russian nuclear signaling to ensure that the norm against "loose nuclear talk" isn't permanently undone. Even though the Kremlin might reap internal and external benefits from creating a belt of insecurity and instability along its borders, its leaders must understand that the concomitant strategy of nuclear intimidation bears enormous risks of inadvertent or accidental escalation with NATO - particularly since many of the stabilizing arms control agreements of the Cold War era are not in place anymore.

Even though the time might not be ripe for a serious dialogue about the "core issues" that trouble NATORussia relations, NATO should step up its efforts to foster continuing talks on current military threats and here, arms control has a valid role to play. As a possible measure, the NRC could be reconstituted as a permanent crisis management forum and mechanism for dialogue, dealing with dangerous military incidents and better communicating each side's intentions. Both NATO and Russia must clearly communicate messages to each other to better manage confrontations, avoid misunderstandings, forestall possible military incidents, and de-escalate tensions. One proposal for the NRC would be to institute a NATO-Russia Memorandum of Understanding to manage dangerous incidents akin to earlier Cold War bilateral agreements between the United States and the Soviet Union. ${ }^{50}$

Once the relationship between Russia and NATO stabilizes, future arms control options could include the consolidation of NATO's tactical nuclear weapons into fewer sites in Europe. In light of recent security concerns, removing US nuclear weapons from Turkey should be discussed among all allies, even if the final decision is up to Washington. Also, transparency talks about numbers and locations of US and Russian nonstrategic nuclear weapons could help to build confidence about the other side's capabilities and intent.

Another helpful measure would be reopening the dialogue on mutual nuclear doctrines. This could be done as part of a larger effort to set up a NATO Center of Excellence on Deterrence with the aim of better communicating to Russia and to the citizens of NATO countries the purpose and means of NATO's deterrence posture.

As for the INF crisis and the interlinked issue of the EPAA, US officials should consider options reassuring Russia about the EPAA vertical launchers, for example by making it technically impossible for them to fire tomahawk cruise missiles. This could be augmented with site visits by Russian military personnel, coupled with reciprocal visits of Russian sites for NATO personnel.

To address possible Russian concerns about thirdcountry nuclear and conventional missiles with intermediate ranges, NATO might reconsider an initiative put forward by Moscow in the United Nations framework during the mid-2000s - that is, multilateralizing the treaty. ${ }^{51}$ In this way, both sides could take account of a changing geopolitical landscape, tackling a problem that may no longer be resolvable in a classical bilateral setting.

All the aforementioned options could provide a face-saving solution for Russia - provided that Russia has convinced the new US administration that it has returned to compliance with the INF Treaty. Washington and its European allies need to remind Moscow again and again of the enormous political and security costs involved from potentially abrogating INF; above all, they need to make clear that without INF, further strategic nuclear dialogue might well be doomed to fail, as well.

To avoid such an outcome, it would be helpful if the Trump administration rethought the general US stance toward missile defense. Since the Russians seem to insist on legally binding limits akin to the ABM Treaty, and given the US Senate's likely resistance to such an approach, the new administration should explore other options for a politically binding accord. That's to say, Washington could use one or both of the European missile defense sites as a bargaining chip, if other issues of US interest - such as Ukraine, INF, or the continued intimidation of NATO's easternmost allies by Russia - are resolved to Washington's satisfaction.

Over the mid- to long-term, NATO and Russia must initiate a serious and open dialog about the two core issues at stake - the freedom and sovereignty of states to seek alliance membership and the (contradicting) Russian interest of maintaining a sphere of influence over its "near abroad." So far, both sides are sticking to their maximum positions, even though both suffer from maintaining them. NATO must ask itself if a possible membership of Ukraine, Georgia, or Moldova really increases the security of its members, and whether the prospect of membership really increases the security of the countries in question. Russia should ask herself why almost all states in its direct neighborhood are eagerly looking for the protection of NATO and the United States, and whether the costs of creating a permanent perception of threat along its borders really serve the long-term interest of the Russian people. 
A well-prepared conference - akin to the 1975 Helsinki Summit, with various preceding rounds of consultations at ambassadorial level, and including the nonaligned states in Europe - might be a way to kick-start the discussion. In any case, the West should not fall prey to false illusions that a change in leadership in Russia will simply end the standoff. Any successor to Putin will fight the prospect of further NATO enlargement, as did all his predecessors.

\section{Editor's note}

This paper was reviewed ahead of publication by Samuel Charap, Senior Fellow for Russia and Eurasia at the International Institute for Strategic Studies.

\section{Disclosure statement}

No potential conflict of interest was reported by the authors.

\section{Funding}

This article is adapted from a paper funded by N.E.X.T. (Nuclear Experts Talks), a project that brings together young and mid-career professionals from Russia, Europe, and the United States with the aim of formulating new approaches to nuclear arms control and disarmament. This project was supported by a grant from the Heinrich Böll Foundation. In the case of Ulrich Kühn, this research was also supported by the Stanton Foundation.

\section{Notes}

1. The unconfirmed Russian strategy of 'escalate to deescalate' implies the limited use of tactical nuclear weapons as a kind of "stop sign" in a crisis where the very existence of the Russian state is under threat. See Sokov, Nikolai N. 2014. "Why Russia Calls a Limited Nuclear Strike 'De-escalation."' Bulletin of the Atomic Scientists. http://thebulletin.org/why-russia-calls-limited -nuclear-strike-de-escalation. While this strategy is a matter of debate amongst Western analysts, particularly due to Russian ambiguity, some have pointed out that it is not (anymore) part of any serious Russian strategy. See Oliker, Olga. 2016. Russia's Nuclear Doctrine. Washington: CSIS. https://csis-prod.s3.amazonaws. com/s3fs-public/publication/160504_Oliker_ RussiasNuclearDoctrine_Web.pdf.

2. In October 2014, as part of the Noble Justification exercises two B-52s flew to Europe. During the Polar Growl exercise on 1 April 2015, four B-52s flew to the Artic and North Sea.

3. Durkalec, Jacek. 2015. Nuclear-Backed "Little Green Men:" Nuclear Messaging in the Ukraine Crisis. July 29. Polish Institute for International Affairs. http:// www.pism.pl/publications/PISM-reports/Nuclear-
Backed-Little-Green-Men-Nuclear-Messaging-in-theUkraine-Crisis.

4. Breedlove, P. 2015. "Commander, US Forces Europe, Prepared Statement to the House Armed Services Committee." February 25. p. 24. http://www.eucom. $\mathrm{mil} /$ media-library/document/31979/u-s-europeancommandposture-statement-2015.

5. Ibid.

6. "NATO Monitoring Russian Sabre Rattling." 2015. Arms Control Today, May. https://www.armscontrol. org/ACT/2015_05/News-Briefs/NATO-MonitoringRussian-Saber-Rattling.

7. NATO. 2015. "NATO's Nuclear Deterrence Policy and Forces." http://www.nato.int/cps/en/natohq/ topics_50068.htm\#.

8. Lucas, Edward, and A. Wess Mitchell. 2014. Central European Security After Crimea: The Case for Strengthening NATO's Eastern Defenses. Report No. 35, March. http://cepa.org/sites/default/files/The\% $20 \mathrm{Case} \% 20$ for $\% 20$ Strengthening $\% 20$ NATOs $\%$ 20Eastern\%20Defenses-\%20(2).pdf.

9. http://www.tvn24.pl/wiadomosci-z-kraju,3/walesapolska-powinna-wypozyczyc-rakiety-ustawic-i-powied ziec-sprobuj-facet-no-sprobuj.464477.html.

10. "Poland Considering Asking for Access to Nuclear Weapons under Nato Program." 2015. The Guardian, December 6. https://www.theguardian. com/world/2015/dec/06/poland-considering-askingfor-access-to-nuclear-weapons-under-nato-program.

11. Secretary of Defense Ash Carter. 2015. "Press Conference by Secretary Carter at NATO Headquarters, Brussels, Belgium.” October 8. http:// www.defense.gov/News/Transcripts/Transcript-View /Article/622454/press-conference-by-secretary-carterat-nato-headquarters-brussels-belgium.

12. NATO Secretary General's Annual Report 2014, January 30, 2015.

13. The 2012 DDPR and 2010 Strategic Concept form the basis of current NATO nuclear policy.

14. "Post-Warsaw Analysis: What NATO Said (or Didn't Say) about Nuclear Weapons." http://www.nti.org/ana lysis/articles/post-warsaw-analysis-what-nato-said-ordidnt-say-about-nuclear-weapons/.

15. "Nuclear weapons are unique. The circumstances in which NATO might have to use nuclear weapons are extremely remote. If the fundamental security of any of its members were to be threatened however, NATO has the capabilities and resolve to impose costs on an adversary that would be unacceptable and far outweigh the benefits that an adversary could hope to achieve.” Warsaw Summit Communiqué, July 9, 2016. http://www.nato.int/cps/en/natohq/official_texts_ 133169.htm.

16. See endote 1 above.

17. 'These Allies' separate centers of decision-making contribute to deterrence by complicating the calculations of potential adversaries." Warsaw Summit Communiqué, July 9, 2016. http://www.nato.int/cps/ en/natohq/official_texts_133169.htm. This sentence also endorses the deterrent value of the British nuclear weapon system whilst demonstrates its commitment to NATO. This is significant in relation to the recent 
Brexit vote to leave the European Union and the concerns over the UK's commitment to Europe more broadly.

18. France's own nuclear deterrent has sea-based and airbased components made up of four Le Triomphant ballistic missile submarines (SSBN), four squadrons of fighter aircraft, and a stockpile of approximately 300 nuclear warheads. It is notoriously conservative about nuclear weapons possession both domestically and also within the NATO context and the least "forward leaning" among the nuclear armed states within the alliance.

19. "The nuclear deterrent remains essential in my view, not just to Britain's security, but as our allies have acknowledged here today, to the overall security of the NATO alliance,' said Cameron, who resigned after last month's EU referendum." Britain sets nuclear vote as NATO underlines need for deterrent, Reuters, July 9, 2016. http://uk.reuters.com/article/uk-nato-summit -britain-idUKKCN0ZP0DQ.

20. The UK's nuclear force is comprised of four Vanguard class ballistic missile submarines (SSBN) with a total stockpile of 120 warheads.

21. NATO does not provide public information on the location or number of the non-strategic nuclear weapons in Europe. Italy and Turkey have taken the decision to purchase the F-35A aircraft which enables these countries to continue to participate in NATO nuclear sharing in Europe. However, Germany is planning to replace its current DCA fleet with nonDCA aircraft, the Eurofighter. Belgium has not yet decided to renew DCA aircraft and in 2013, the Netherlands government passed a motion for a nonnuclear aircraft. This presents possible challenges to continuing the nuclear-sharing arrangements all of the existing hosting countries Europe.

22. "Video Shows Earth-Penetrating Capability of B61-12 Nuclear Bomb." https://fas.org/blogs/security/2016/ 01/b61-12_earth-penetration/.

23. "The B61 Life-Extension Program: Increasing NATO Nuclear Capability and Precision Low-Yield Strikes." https://fas.org/issue-brief/b61-life-extension-programincreasing-nato-nuclear-capability-precision-low-yieldstrikes/.

24. To deploy the non-strategic gravity B-61 bombs, Belgium, Turkey, and the Netherlands currently have F-16s and Germany and Italy have PA-200 Tornado aircraft. The decision to replace these aircraft has been and will continue to be contentious in some of the European hosting countries, particularly Germany, the Netherlands, and Belgium. These countries have been managing domestic pressure from their parliaments and publics to remove these weapons and stop their participation in NATO's nuclear sharing arrangement. After the DDPR was agreed, an uneasy consensus was agreed to continue the nuclear mission in Europe. In the coming decade, procurement decisions about new DCAs will still need to be made by Germany, Belgium, and the Netherlands and they, along with Italy and Turkey, will also need to introduce the modernized B-61-12s. This may present difficulties in continuing the nuclear-sharing mission in the future. Yet, despite the domestic challenges, the forward basing arrangement and deployment of non-strategic nuclear weapons in Europe is likely to continue.

25. "B61 LEP: Increasing NATO Nuclear Capability and Precision Low-Yield Strikes.” FAS, June 15, 2011. http://fas.org/blogs/security/2011/06/b61-12/.

26. "General Cartwright Confirms B61-12 Bomb 'Could Be More Useable'.” https://fas.org/blogs/security/ 2015/11/b61-12_cartwright/.

27. "LEPs will use only nuclear components based on previously tested designs and will not support new military missions or provide for new military capabilities. The United States will not develop new nuclear warheads." U.S. Nuclear Weapons Stockpile Life Extension Programs, Fact Sheet, Bureau Of Arms Control, Verification, And Compliance. http://www. state.gov/t/avc/rls/202015.htm.

28. Russia's non-strategic nuclear weapons are reportedly kept in storage, not forward deployed with delivery units.

29. Zagorski, Andrei. 2011. Russia's Tactical Nuclear Weapons: Posture, Politics and Arms Control. Hamburg: IFSH, p. 7. https://www.files.ethz.ch/isn/ 127021/hb156.pdf.

30. Although not officially mentioned in Moscow, China is also a great concern for the Russian defense establishment.

31. Podvig, Pavel. "Missile Defense and the Myth of Strategic Stability.” http://russianforces.org/podvig/Podvig-Missile \%20defense\%20and\%20strategic\%20stability.pdf.

32. "Russia Warns Czech Republic, Poland On Missile Defense." http://www.rferl.org/content/article/ 1074816.html. Even though missile defense was regularly referred to by Russian decision-makers as a reason for the suspension of CFE, the 2002 decision by NATO not to ratify the Adapted CFE Treaty together with continuing rounds of NATO enlargement had a decisive impact on the Russian decision as well.

33. Pifer, Steven. "Will Russia Take 'Yes' for an Answer?" https://www.brookings.edu/opinions/will-russia-takeyes-for-an-answer/.

34. Giles, Keir, and Andrew Monaghan. 2014. European Missile Defense and Russia, United States Army War College Press, July. According to Russian sources, the new road-mobile "Yars" and "Yars-M" ICBMs as well as the new "Sarmat" ICBM are designed with the potential to counter and defeat any missile defense system.

35. Medvedev. "Statement in Connection with the Situation Concerning the NATO Countries' Missile Defence System in Europe." November 23, 2011. http://en.kremlin.ru/events/president/news/13637.

36. Levis, Jeffrey. 2015. "Sokov on Russian Cruise Missiles." Arms Control Wonk, August 25. http:// www.armscontrolwonk.com/archive/207801/sokov-on -russian-cruise-missiles/.

37. The Polish site is currently under construction and is planned to be equipped with SM-3 IIA launchers. Its completion is slated for 2018. V Sevastopol pribudut kobrabli s raketami “Kalibr”, https://regnum.ru/news/ polit/2012964.html. 
38. "US Missile Defense in Eastern Europe: How Russia Will Respond." Military and Intelligence, 15.05.2016, http://sputniknews.com/military/20160516/ 1039683754/us-missile-defense-europe-russianresponse.html.

39. This part builds on some elements of an earlier draft, jointly written by Ulrich Kühn and Anna Péczeli.

40. US Department of State, 2016 Report on Adherence to and Compliance With Arms Control, Nonproliferation, and Disarmament Agreements and Commitments, 11 April 2016.

41. Gordon, Michael R. 2017. "Russia Has Deployed Missile Barred by Treaty, U.S. General Tells Congress." The New York Times, March 8. https:// www.nytimes.com/2017/03/08/us/politics/russia-infmissile-treaty.html?_r=0.

42. Gordon, Michael R. 2017. "Russia Deploys Missile, Violating Treaty and Challenging Trump." New York Times, February 14. https://www.nytimes.com/2017/ 02/14/world/europe/russia-cruise-missile-armscontrol-treaty.html?_r=0.

43. The Ministry of Foreign Affairs of the Russian Federation, Comment by the Information and Press Department on the US Department of State's report on adherence to and compliance with arms control, nonproliferation, and disarmament agreements and commitments, 15 April 2016.

44. See The Deep Cuts Commission, Back from the Brink, June 2016, pp. 23 et. seq. http://deepcuts.org/images/ PDF/Third_Report_of_the_Deep_Cuts_Commission_ English.pdf.

45. Ibid.

46. One such option might be for the next US Administration to close the so-called capability gap and focus on weapons systems which are currently prohibited under INF. See Burns, Robert. 2015. "United States might Deploy Missiles in Europe to Counter Russia." Associated Press. June 4. http://news.yahoo.com/us-might-deploy-missiles-europe -counter-russia-185508867.html.

47. In 2005, then-US Secretary of Defense Donald Rumsfeld commented that he would not mind if Russia withdrew from the INF Treaty, thus indicating that also the United States had no real interest in the treaty. See Lewis, Jeffrey. 2014. "An Intercontinental Ballistic Missile by any Other Name.” Foreign Policy
Magazine. http://foreignpolicy.com/2014/04/25/anintercontinental-ballistic-missile-by-any-other-name/.

48. Charap, Samuel, and Jeremy Shapiro. 2016. "USRussian Relations: The Middle Cannot Hold." Bulletin of the Atomic Scientists 72 (3): 150-155.

49. This pledge was formalized in the 1997 NATO-Russia Founding Act.

50. See Kearns, Ian, and Denitsa Raynova. 2016. "Managing Dangerous Incidents: The Need for a NATO-Russia Memorandum of Understanding." European Leadership Network, March 7. http://www. europeanleadershipnetwork.org/managing-dangerousincidents-the-need-for-a-nato-russia-memorandumof-understanding_3578.html.

51. The latest remarks by Vladimir Putin point in that direction. Meeting of the Valdai International Discussion Club (27 October 2016), Remarks by Vladimir Putin. http://en. kremlin.ru/events/president/news/53151.

\section{Notes on contributors}

Ulrich Kühn is a Stanton Fellow at the Nuclear Policy Program, Carnegie Endowment for International Peace. His focus is on NATO-Russian relations, nuclear and conventional arms control and deterrence, and European security in general. His articles have appeared in a wide range of publications, including Arms Control Today, Foreign Affairs, The National Interest, and War on the Rocks.

Shatabhisha Shetty is Deputy Director and cofounder of the European Leadership Network and runs the British crossparty parliamentary group, the Top Level Group for UK Parliamentarians for Multilateral Nuclear Disarmament and Non-Proliferation. Prior to this role, she worked in the in the Nuclear Analysis Program at the Royal United Services Institute for Defence and Security Studies (RUSI).

Polina Sinovets is an associate professor in the international relations department at Odessa I.I. Mechnikov National University, Ukraine and Head of the Odessa Center for Nonproliferation. Before that, she was a senior research associate at Ukraine's National Institute for Strategic Studies. She has published several dozen articles on nuclear deterrence, disarmament, missile defense, and nonproliferation in Ukrainian, Russian, and English. 